ISBN 978-93-84422-76-9

International Conference on Research \& Innovation in Environment, Civil and Architecture Engineering

(RIECAE-17)

Bangkok (Thailand), Feb. 6-7, 2017

\title{
The Selection Factors of Reused Old House in Tainan Historical Districts: A Case Study of Commercial Use of the Old Houses
}

\author{
Jing-Tang Zhang ${ }^{\mathrm{a}}$, and Hsien-Hsien Cheng ${ }^{\mathrm{b}}$ \\ ${ }^{a}$ Graduate student, Department of Urban Planning, National Cheng-Kung University, Taiwan \\ a6854516@gmail.com \\ ${ }^{\mathrm{b}}$ Associate Professor, Department of Urban Planning, National Cheng-Kung University, Taiwan \\ janeshin@mail.ncku.edu.tw
}

\begin{abstract}
The atmosphere of reused old house in Tainan began to flourish since 2008. The numbers of reused old house are rising continuously in Tainan till now. The ways of operation are variety, most of them were used as a business place, like coffee shop, restaurant, handmade work shop and studio. This research is to discuss what factors prompted these proprietors to choose the old houses to reuse. Even though the researches past deeply know the situation of the subjects with the method of Qualitative Research but they couldn't understand the phenomenon of whole Tainan historical districts because they all focus on specific areas or streets before. Therefore the study will discuss the selection factors of reused old house in Tainan historical districts by hedonic price model. Two research objectives are as follows:

1) By comparison of economic viewpoints and general site selection factors, whether the situation of the selection factors of reused old house in Tainan historical districts is a special case?

2) According to the implying meaning of rent by Hedonic Price method, the study will try to analysis which factors would proprietors consider for the old house reused
\end{abstract}

Keywords: reused old houses, selection factor, Tainan historical districts, hedonic price model

\section{Introduction}

The cultural atmosphere is made up of monuments, old alleys and old houses. Comparing with the monuments and gorgeous old houses, the general old house is much more close to lives of ordinary people and the basic atmosphere of the Tainan historic district. Therefore, the old houses perform the process of Tainan history. As the development, the old houses become idle or torn down. However, the public begins to respect, preserve and reuse the old houses since the government implements the Cultural property conservation law and subsidy about reused old houses.

The motivation is to know what factors caused the proprietors to choose the old houses to reuse in commercial way. The researches past deeply know the situation of the subjects including the selection factors with the method of Qualitative Research. They limited to the specific areas or streets so that they couldn't understand the thinking of the whole proprietors in whole historical districts. The reason why choosing the reused old house in commercial is that there are at least 1000 old houses in this area but not all of them were reused. Most reused old houses were commercial use except for traditional shop. The proprietors most of them are young create new functions and make the old house keep working in new form like coffee shop, restaurant, handmade work shop and studio. The new way of using old house let the life of the old houses be extended.

The research tries to use hedonic price model to analyze the selection factors through the implied meaning of the old houses' rent and to compare reused old houses' selection factors with the normal shop sites' selection factors. Taking the whole Tainan historical district as the area of research is to understand the general selection factors of reused old house. After the field study, there are 145 reused old houses in the area. 


\section{Literature Reviews}

According to the Tainan City Historic District Revitalization Autonomy Ordinance, the definition of the old house is a building full of history, culture and preservation value or had been built before 1971. 《Encyclopedia of Architecture, Design Engineering \& Construction》 had made the definition of reuse: by creating a new functions or reconfiguration let the building to continue to use in new way which could meet its demand. A reused old house allows us to see the value of its past and turn it into new energy(Ya-Jyun Lin , 2011).

The atmosphere of reused old houses in Tainan began to flourish since 2008, then more and more related researches have been output. Most of them illustrate the old houses are the basis for the historical atmosphere of Tainan. While paying attention to the history and culture of Tainan, we should not just focus on the monuments but also the old houses. Old houses are the stories, ideas and memories. Jane Jacob mentions urban diversity is of great importance, only in combination do they lead to the diversity that is needed for a blossoming city life. The core of process about reused old house is the owner of the old house, and the proprietors will be normed by the owner. Because of the traditional thinking of inheritance, most of the reused old houses were rented. The reused old houses locate on alley more than street and road. The selection of reused old house is different from the selection of shop site. There is no more crowded and traffic but relies on the type of old houses and the environmental atmosphere (Jin-ling Jan,2014 and Szu-Wen Fang, 2015). Location and area which impact the proprietors are the important selection (Hsien-Hsien Cheng, 2013 and Su-Han Tsai, 2016).

According to Principle of Minimum Differentiation and Bid Rent Theory, the proprietors must choose the site which could get the greatest benefits. Also, the different industries would choose different site. The factors are different from the factors of reused old house, including population, consumption, environment, competition, cooperation, traffic, location, legal and financial.

The hedonic price model based on consumption theory was developed by Lancaster(1966). If we discuss the hedonic price of the house price we could know the relationship between people and market. We can understand people's preference of the environment by regression model. Lots of researchers use the hedonic price model to discuss on interpreting environmental factors which influence the rent, house price or land value.

\section{Research Design}

\subsection{Research procedure}

The research will be divided into three sections. The first one is the basic data collecting and the related literature analyzing, in order to build the basic research infrastructure. Second, to use the hedonic price model and the last is to write the conclusion and advice. The procedure is shown below.

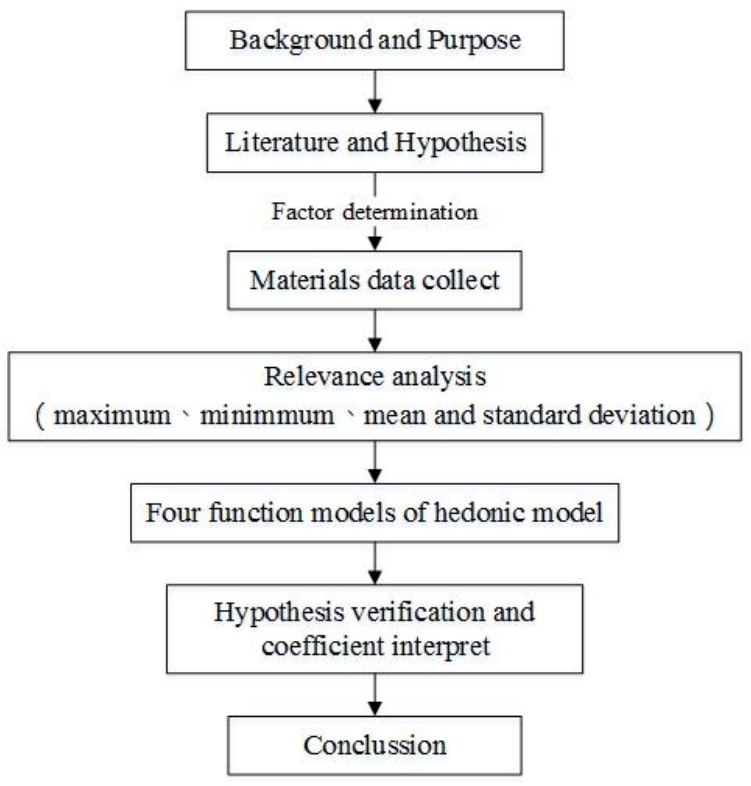

Fig. 1 procedure 


\subsection{Research Method}

The necessary factors will be gotten by field research and they will be divided into general site selection factors and reused old houses' selection factors. Afterwards, it will use four regression model of hedonic price model linear, semi-log, inverse semi-log and log-linear. By comparing with each other, the best model will interpret the meaning of coefficient and preference of proprietor by analyzing the factors on rent.

\subsection{Research hypothesis}

The hypothesis will be divided into general site selection factors and reused old houses' selection factors. According to the literatures, the general site selection factors are not the priority of the proprietors' selection. It doesn't depend on lots of people and traffic but on the type of old house and atmosphere of environment. So the hypothesis shows below:

- $\quad$ General site selection factors

H1: If the environment around the old houseis busier, the proprietors will not use the old house.

H2: If the general site selection factors is more superior, the proprietors will not use the old house.

- $\quad$ Reused old houses' selection factors

H3: If the frontage and building type of old house is more brilliant, the proprietors will use the old house.

H4: If the historical atmosphere surround is stronger, the proprietors will use the old house.

- $\quad$ Other selection factors

《The analysis of the historical building reusing in Kaohsiung》, Hsien-Hsin Cheng(2013) and Su-HanTsai(2016) points out the historical old houses are in the prime location of the city. The location, area and land value are the important factors. Consequently, the study will preliminary study the relationship between reused old houses' selection factors and land value.

\subsection{Variable setting}

Based on the hypothesis above, the variables will be set as the following. Under Chinese traditional concept of inheritance, the reused old houses are mainly based on rent (Ya-Jyun Lin , 2011). Therefore the Dependent variable of the study will be rent.

TABLE I: Variable Setting

\begin{tabular}{|c|c|c|c|c|}
\hline & Variable name & Variable code & Description & Unit \\
\hline 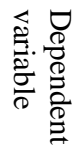 & Rent & Rent & The rent of old house & $\begin{array}{l}\text { Ten thousand } \\
\text { dollar }\end{array}$ \\
\hline \multirow{2}{*}{ 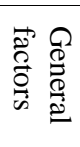 } & $\begin{array}{c}\text { Year tourist } \\
\text { number }\end{array}$ & Tour_n & $\begin{array}{l}\text { The annual tourist number of sightseeing spot } \\
\text { nearest to the old house }\end{array}$ & $\begin{array}{l}\text { Ten thousand } \\
\text { people }\end{array}$ \\
\hline & Frontage width & B_wide & $\begin{array}{l}\text { How wide the frontage width of the old house } \\
\text { is }\end{array}$ & Meter \\
\hline \multirow[b]{2}{*}{$\stackrel{\mathscr{\sigma}}{\overrightarrow{0}}$} & Road width & Road_w & How width the road in front of the old house is & Meter \\
\hline & $\begin{array}{c}\text { Distance to } \\
\text { main road }\end{array}$ & Mroad_d & $\begin{array}{l}\text { The distance between the old house and the } \\
\text { nearest main road }\end{array}$ & Meter \\
\hline \multirow{2}{*}{ 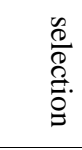 } & $\begin{array}{l}\text { Distance to bus } \\
\text { stop }\end{array}$ & Bus_d & $\begin{array}{l}\text { The distance between the old house and the } \\
\text { nearest bus stop }\end{array}$ & Meter \\
\hline & $\begin{array}{l}\text { Distance to } \\
\text { parking lot }\end{array}$ & Parking & $\begin{array}{l}\text { The distance between the old house and the } \\
\text { nearest parking lot }\end{array}$ & Meter \\
\hline \multirow{7}{*}{ 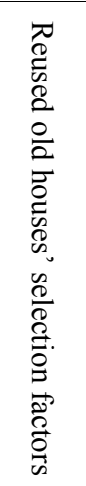 } & \multirow{7}{*}{ Building type } & B_formCS & $\begin{array}{l}\text { Whether it is the Qing street house or not. } \\
\text { (Yes:1, No:0) }\end{array}$ & \multirow{7}{*}{ Dummy variable } \\
\hline & & B_formCH & $\begin{array}{l}\text { Whether it is the Qing Pan-Lou-Tzu building } \\
\text { or not. (Yes:1, No:0) }\end{array}$ & \\
\hline & & B_formCC & $\begin{array}{l}\text { Whether it is the san ho yuan or not. (Yes:1, } \\
\text { No:0) }\end{array}$ & \\
\hline & & B_formJS & $\begin{array}{l}\text { Whether it is the Japanese street house or not. } \\
\text { (Yes: } 1, \text { No:0) }\end{array}$ & \\
\hline & & B_formJR & $\begin{array}{l}\text { Whether it is the Japanese residence or not. } \\
\text { (Yes:1, No:0) }\end{array}$ & \\
\hline & & B_formJD & $\begin{array}{l}\text { Whether it is the Japanese dormitory or not. } \\
\text { (Yes:1, No:0) }\end{array}$ & \\
\hline & & B_formRS & $\begin{array}{l}\text { Whether it is the post-war street house or not. } \\
\text { (Yes:1, No:0) }\end{array}$ & \\
\hline
\end{tabular}




\begin{tabular}{|c|c|c|c|c|}
\hline & \multirow[t]{5}{*}{ Variable name } & Variable code & Description & Unit \\
\hline & & B_formRC & $\begin{array}{l}\text { Whether it is the post-war congregate housing } \\
\text { or not. (Yes:1, No:0) }\end{array}$ & \\
\hline & & B_formRR & $\begin{array}{l}\text { Whether it is the post-war residence or not. } \\
\text { (Yes: } 1, \text { No:0) }\end{array}$ & \\
\hline & & B_formRP & $\begin{array}{l}\text { Whether it is the post-war public building or } \\
\text { not. (Yes:1, No:0) }\end{array}$ & \\
\hline & & B_formO & $\begin{array}{l}\text { Whether it is the other building type or not. } \\
\text { (Yes:1, No:0) }\end{array}$ & \\
\hline & Building age & B_age & How old the old house is & Year \\
\hline & $\begin{array}{l}\text { Building } \\
\text { facade }\end{array}$ & B_look & $\begin{array}{l}\text { How splendid the facade of the old house is } \\
\text { (3:Spendid, 2:pretty good, } 1: \text { common) }\end{array}$ & Dummy variable \\
\hline & $\begin{array}{c}\text { Distance to } \\
\text { monument }\end{array}$ & His_d & $\begin{array}{l}\text { How far the distance between the old house and } \\
\text { the nearest monument is }\end{array}$ & Meter \\
\hline & $\begin{array}{l}\text { Distance to old } \\
\text { street }\end{array}$ & Opath_d & $\begin{array}{l}\text { How far the distance between the old house and } \\
\text { the nearest old street is }\end{array}$ & Meter \\
\hline & $\begin{array}{l}\text { Monument } \\
\text { number }\end{array}$ & His_n & How many monuments surround old house & Unit \\
\hline & $\begin{array}{c}\text { Old house } \\
\text { number }\end{array}$ & Oh_n & $\begin{array}{l}\text { How many reusd old houses surround old } \\
\text { house }\end{array}$ & Unit \\
\hline 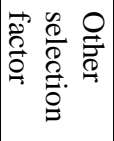 & Land value & Landvalue & $\begin{array}{l}\text { How much land value of the location of the old } \\
\text { house is }\end{array}$ & $\begin{array}{l}\text { Ten thousand } \\
\text { dollar }\end{array}$ \\
\hline
\end{tabular}

\section{Data Analysis}

The samples are based on the old houses which had been reused before 2016/10. After the field research, there are 145 reused old house in Tainan historical districts. As the Fig. 2 shows, most of the reused old houses spread out the streets or blocks. According to the overlay, the streets appeared during the modern urban planning of Tainan city under the Japanese rule, like Zhongzheng Road, Zhongshan Road and Minquan Road.

Most of reused old houses were used by rented and the average of the rent is about 25,000 thousand/month. The maximum of the rent is 68,600 thousand/month. The year tourist number refers to the statistical data of Tainan government and the sightseeing spots include Tainan Grand Matsu temple, Confucious Temple, Chihkan Tower, Koxinga Shrine and The Si Dian Wu Miao. The average of the year tourist number is about 560,000 and the maximum is 840,000 . In addition, the relationship between reused old houses and roads can be discovered by Autocad and ArcGIS. The average width of road or street in front of reused old house is 9.8 meters and the average of distance to main road is 82.3 meters. The average distance to bus stop is 85.4 meters. The nearest is 6 meters and the farthest is 250 meters. The average distance to parking lot is 221.8 meters. According to the research of Government, the optimum walking distance is about 400-800 meters, so the distance of bus stops and parking lots are still within the scope. The average width of the frontage is about 5.8 meters and the average of age is about 66.9 years. The reused old houses and the monuments are very close. The average distance to monument is about 81.6 meters and the average number of monuments surrounding reused old house is about 14.9. The maximum is 30 , thus we can find that the density is very alarming. Most reused old houses are close to the old streets and the average distance to Old Street is 20 meters. The number of the reused old houses surrounding it is about 7.9. On the other way, the average of the land value is about 79,000. The maximum is 191,000 and the minimum is only 27,000 . 


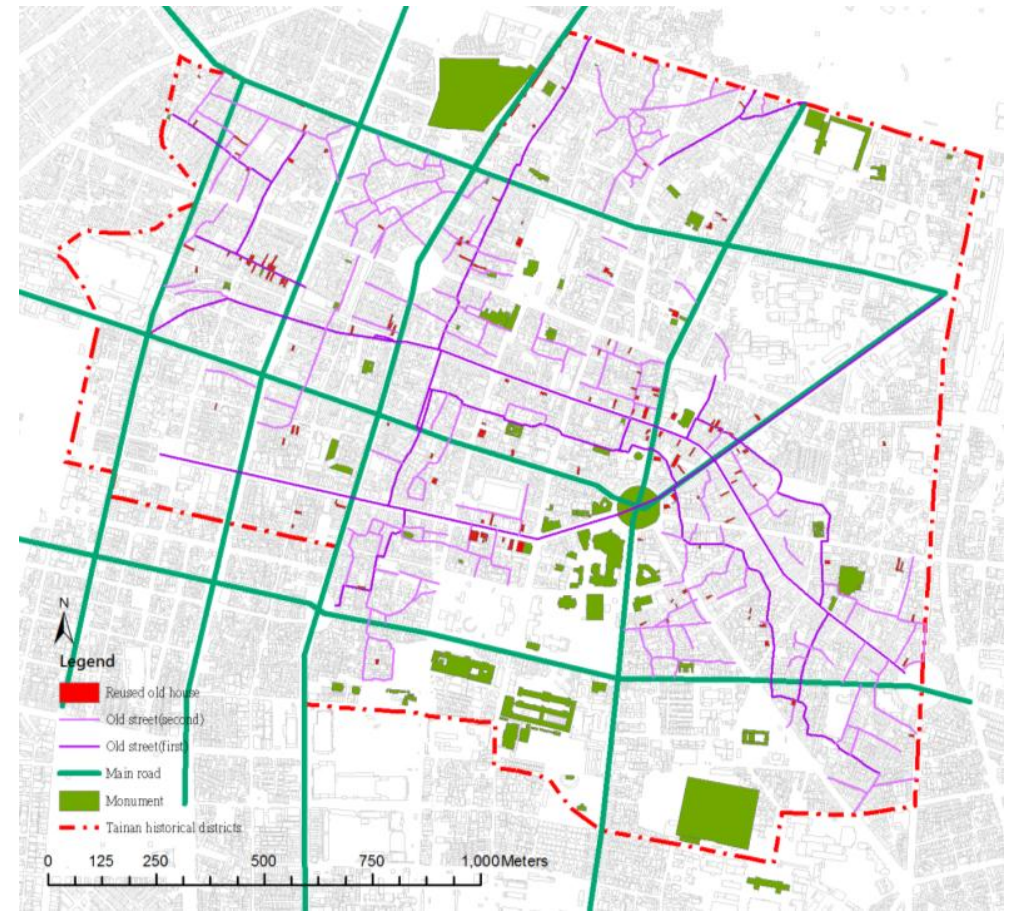

Fig. 2 Reused old houses distribution map

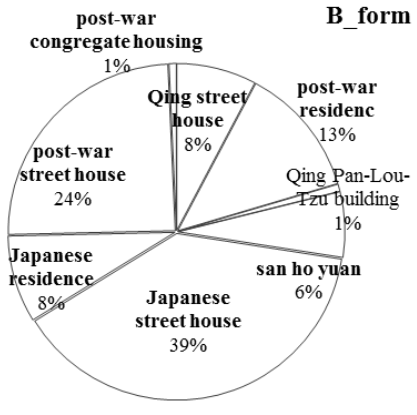

Fig. 3 B_form charts

B_look

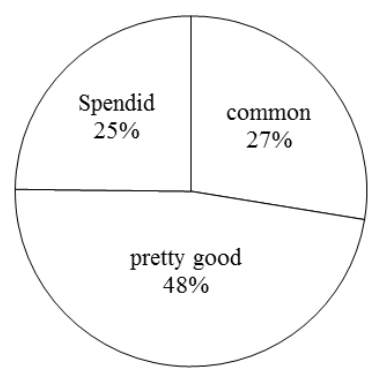

Fig. 4 B_look charts

TABLE II: Reused old house statistics

\begin{tabular}{|l|r|r|r|r|}
\hline Variable name & Minimum & Maximum & \multicolumn{1}{c|}{ Mean } & $\begin{array}{c}\text { Standard } \\
\text { deviation }\end{array}$ \\
\hline Rent & .00 & 6.86 & 2.5721 & 1.48188 \\
\hline Tour_n & 21 & 84 & 56.27 & 23.213 \\
\hline B_wide & 2.30 & 19.00 & 5.8869 & 2.86585 \\
\hline Road_w & .00 & 23.60 & 9.8745 & 7.78525 \\
\hline Mroad_d & 7 & 275 & 82.32 & 57.537 \\
\hline Bus_d & 6 & 250 & 85.49 & 48.214 \\
\hline Parking & 18 & 591 & 221.80 & 111.059 \\
\hline B_age & 45 & 121 & 66.97 & 21.132 \\
\hline His_d & 0 & 324 & 81.63 & 60.779 \\
\hline Opath_d & 0 & 266 & 20.08 & 40.073 \\
\hline His_n & 1 & 30 & 14.93 & 8.184 \\
\hline Oh_n & 5 & 67 & 37.48 & 13.944 \\
\hline Landvalue & 2.71 & 19.13 & 7.9394 & 145 \\
\hline Reused old house total & & & \\
\hline
\end{tabular}

Japanese street house is the largest proportion of the building type and it is about $39 \%$. The second is the postwar street house (24\%) and the third is post-war residence(13\%). In Building facade section, "pretty good" is the largest proportion and it is about $48 \%$. It is surprising that "spendid" is the last and it is only $25 \%$.

\section{Regression Analysis}

TABLE III: Regression of Hedonic price model

\begin{tabular}{|c|c|r|r|r|r|r|r|r|}
\hline & \multicolumn{2}{|c|}{ linear } & \multicolumn{2}{c|}{ Semi-log } & \multicolumn{1}{c|}{ Inverse semi-log } & \multicolumn{2}{c|}{ log-linear } \\
\cline { 2 - 9 } & $\boldsymbol{t}$ & \multicolumn{1}{c|}{ Sig. } & \multicolumn{1}{c|}{$\boldsymbol{t}$} & \multicolumn{1}{c|}{ Sig. } & \multicolumn{1}{c|}{} & \multicolumn{1}{c|}{ Sig. } & \multicolumn{1}{c|}{} & \multicolumn{1}{c|}{ Sig. } \\
\hline constant & 1.919 & 0.057 & -2.020 & 0.045 & 1.537 & 0.127 & 2.626 & 0.01 \\
\hline Tour_n & 1.118 & 0.266 & 1.536 & 0.127 & 1.461 & 0.147 & 1.367 & 0.174 \\
\hline B_wide & 0.376 & 0.707 & 0.097 & 0.923 & -0.170 & 0.865 & 0.250 & 0.803 \\
\hline Road_w & 0.827 & 0.410 & 0.156 & 0.877 & 0.997 & 0.321 & 0.702 & 0.484 \\
\hline Mroad_d & -1.078 & 0.283 & -0.838 & 0.404 & -0.892 & 0.374 & -0.911 & 0.364 \\
\hline Bus_d & 1.335 & 0.184 & 0.268 & 0.789 & 1.594 & 0.113 & 0.100 & 0.921 \\
\hline
\end{tabular}




\begin{tabular}{|c|c|c|c|c|c|c|c|c|}
\hline & \multicolumn{2}{|c|}{ linear } & \multicolumn{2}{|c|}{ Semi-log } & \multicolumn{2}{|c|}{ Inverse semi-log } & \multicolumn{2}{|c|}{ log-linear } \\
\hline & $t$ & Sig. & $t$ & Sig. & $t$ & Sig. & $t$ & Sig. \\
\hline Parking & 0.602 & 0.548 & 2.111 & $0.037 * *$ & -0.221 & 0.826 & 2.073 & $0.040 * *$ \\
\hline B_formCS & -0.522 & 0.603 & -0.921 & 0.359 & -0.685 & 0.495 & -0.848 & 0.398 \\
\hline B_formCH & -0.316 & 0.752 & 0.103 & 0.918 & -1.133 & 0.259 & -0.007 & 0.994 \\
\hline B_formCC & -1.316 & 0.191 & -0.387 & 0.699 & -1.731 & $0.086^{*}$ & -0.415 & 0.679 \\
\hline B formJR & -0.584 & 0.561 & 0.121 & 0.904 & -0.609 & 0.543 & 0.423 & 0.673 \\
\hline B formRS & -0.007 & 0.994 & -0.114 & 0.909 & -0.331 & 0.741 & -0.059 & 0.953 \\
\hline B_formRC & -1.270 & 0.207 & -1.693 & $0.093 *$ & -1.769 & $0.079 *$ & -1.630 & 0.106 \\
\hline B_formRR & -1.258 & 0.211 & -0.731 & 0.466 & -1.430 & 0.155 & -0.694 & 0.489 \\
\hline B_age & 0.607 & 0.545 & 0.321 & 0.749 & 0.854 & 0.395 & 0.379 & 0.706 \\
\hline B look & -0.641 & 0.523 & -1.102 & 0.272 & -1.133 & 0.260 & -1.015 & 0.312 \\
\hline His $d$ & -5.155 & $0.000 * * *$ & -4.527 & $0.000 * * *$ & -5.072 & $0.000 * * *$ & -4.605 & $0.000 * * *$ \\
\hline Opath_d & -2.421 & $0.017 * *$ & -2.958 & $0.004 * *$ & -2.487 & $0.014 * *$ & -2.923 & $0.004 * *$ \\
\hline His_n & 0.008 & 0.994 & 0.704 & 0.483 & -0.048 & 0.962 & 0.506 & 0.614 \\
\hline $\mathrm{Oh} \_\mathrm{n}$ & 0.040 & 0.968 & -0.202 & 0.840 & 0.008 & 0.993 & -0.054 & 0.957 \\
\hline Landvalue & 1.857 & $0.066 *$ & 2.941 & $0.004 * *$ & 1.513 & 0.133 & 2.401 & $0.018 * *$ \\
\hline $\mathrm{F}$ & & 4.318 & & 4.780 & & 4.542 & & 4.541 \\
\hline $\mathrm{R}$ & & 0.641 & & 0.660 & & 0.650 & & 0.650 \\
\hline R2 & & 0.411 & & 0.435 & & 0.423 & & 0.423 \\
\hline Adj R-sq & & 0.315 & & 0.344 & & 0.330 & & 0.330 \\
\hline sample & & 145 & & 145 & & 145 & & 145 \\
\hline
\end{tabular}

a. SPSS excludes the variable B_formJS in all four models

b. ***,**,* represent the significance level of $1 \%, 5 \%, 10 \%$ respectively

After the SPSS analysis, the variables of the study don't have the situation of collinearity (VIF $<10)$. The best model of all is Semi-log model and its R2 is 0.435. According to table IV, the R2 of the Semi-log model is enough to be dependable.

TABLE IV: R2 explanation parallel text

\begin{tabular}{|r|r|r|r|r|r|r|r|r|}
\hline & \multicolumn{4}{|c|}{$\begin{array}{c}\text { Significance Level }(\boldsymbol{a})=0.01 \\
\text { No. of Independent Variables }\end{array}$} & \multicolumn{3}{|c|}{$\begin{array}{c}\text { Significance Level }(\boldsymbol{a})=0.05 \\
\text { No. of Independent Variables }\end{array}$} \\
\hline $\begin{array}{c}\text { Sample } \\
\text { Size }\end{array}$ & 2 & 5 & 10 & 20 & 2 & 5 & 10 & 20 \\
\hline 20 & 45 & 56 & 71 & NA & 39 & 48 & 64 & NA \\
\hline 50 & 23 & 29 & 36 & 49 & 19 & 23 & 29 & 42 \\
\hline 100 & 13 & 16 & 20 & 26 & 10 & 12 & 15 & 21 \\
\hline 250 & 5 & 7 & 8 & 11 & 4 & 5 & 6 & 8 \\
\hline 500 & 3 & 3 & 4 & 6 & 3 & 4 & 5 & 9 \\
\hline 1,000 & 1 & 2 & 2 & 3 & 1 & 1 & 2 & 2 \\
\hline
\end{tabular}

a.NA=not applicable

b. Source:Multivariate Data Analysis sixth Edition, Joseph F. Hair, Jr(2005), P.195

The Regression formula of reused old house is as follows:

$$
\begin{aligned}
& \text { Rent }=-2.02+1.536 \text { Tour_n }+0.097 B \_ \text {wide }+0.156 \text { Road_w }-0.838 \text { Mroad_d }-0.838 B u s \_d
\end{aligned}
$$

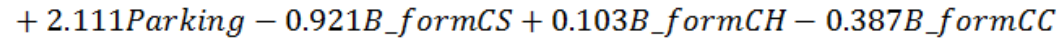

$$
\begin{aligned}
& +0.121 B_{-} \text {formJR }-0.144 B_{-} \text {formRS }-1.693 B_{-} \text {formRC }-0.731 B_{-} \text {formRR } \\
& +0.321 B \_a g e-1.102 B \_l o o k-4.527 \text { His_d }-2.9580 \text { path_d }+0.704 H i s \_n \\
& -0.2020 h \_n+2.941 \text { Landvalue }
\end{aligned}
$$

The preliminary research results shows part of the selection factors are the same as past but most of them refute. The Consistent part is that the proprietors prefer Qing Pan-Lou-Tzu buildings and Japanese residences. The age of the building is the older the better. The proprietors all like the atmosphere of historical environment and the component of the atmosphere of historical environment are monument, old house and Old Street. If the old houses are closer to monuments and old streets, the proprietors more likely reuse the old house. The assume $\mathrm{H} 4$ is valid.

The inconsistent part is that the proprietors still consider the general site selection factors. The proprietors 
prefer wider road and frontage, closer to main roads and bus stops. The number of tourist is the bigger, the better. But they want to stay away from the parking lots. On the part of reused old houses' selection factors the building facade shows negative correlation. There may be two reason. If facade is more splendid, the funds of maintenance and management will be higher. On the other way, the judgement of facade is a profession. An old house has lots of components. The proprietors can't judge them, they still based on their own feelings. The

proprietors want to use the reused old house in the surrounding is the less the better. It can be interpreted that

they want to avoid industry competition. All of them are the same industry and the theme of the old house atmosphere are the same. Based on the result the assume H1, H2 and $\mathrm{H} 3$ are invalid.

In addition, the reused old houses can be found on the site which the land value is higher. The overlay of land value and rent can be seen that the areas with high rent overlap with the high land value. But there are some area with high rent overlap with the low land value. The situation is similar to the research result of Shu-Li Huang, it points out that the atmosphere of reused old house flourish. It begins to excessive commercial speculation and cause the rent has been raised. However, this study is an only preliminary found in this phenomenon, it can't be in-depth study.

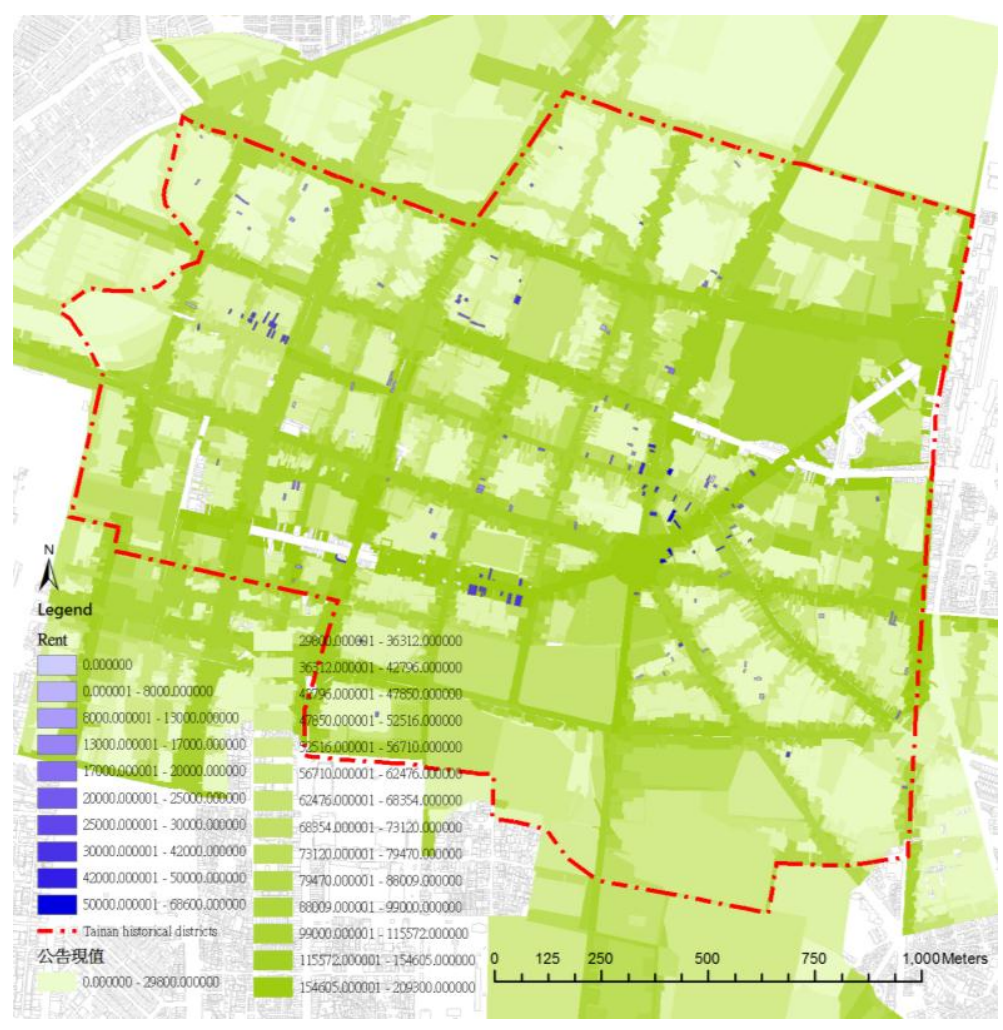

Fig. 5 Rent and Land value distribution map

\section{Conclusion}

The study uses the Hedonic price model which is the Quantitative methods to discuss the whole Tainan historical districts. It can complement the defect of the researches past which were studied in specific areas. The specific areas include Xinmei Street, Xinyi Street or Shennong Street and all of them are flourishing areas. Consequently, the research result past can't interpret the phenomenon the reused old house in Tainan historical districts.

According to the result, the proprietors prefer the old houses with historical and cultural atmosphere of the area. The monuments around are significant. The proprietors may consider the general site selection factors including near main roads, bus stops and lots of tourists. This part of the discovery is the biggest difference with the research in the past. In addition, discussing with the land value can discover that the reused old houses locate the site with the higher land value.

The result presently can't do a more detail discussion with the factor. For example, the study takes all monuments as homogeneity. In fact, the monuments can be separated into several types. The location of reused old houses can separate into road, street and corner. There can be much more selection factors to discuss with, even. It includes the structure of building, land use and the distribution of old trees or Furui. So that it can have more in-depth and extensive discussion of the selection factors of reused old houses.

Some selection factors have the problem of time course like land value. The result presently can only interpret the relationship between land value and rent but it can't interpret why the reused old house locate in the area with the higher land value. It is necessary to examine and classify the selection factors which also have the problem of time course. So that it could understand the thinking of proprietors through the time changing. 
In addition, many researches point out that Hedonic price model has the problem of Spatial Dependence. Subsequent studies may detect the spatial autocorrelation (Moran's I) with the rent. Whether the dependent variable of the model has Spatial Dependence or not. If it has the problem, it will use the Spatial Hedonic price model to enhance the explanatory power of the model.

\section{References}

[1] Tsai, S. H. (2016). "The Research of Conversion of Old Houses Based on the Creative Cluster - A Case Study of Xinmei Street and Minquan Road Surrounding Area in Tainan City [in Chinese]." (Master thesis), National Cheng Kung University, Tainan.

[2] Wang, C. Y. (2015). "Exploring the revitalization attributes of old houses and the key factors influencing visitors' revisit intentions [in Chinese]." (Master thesis), Southern Taiwan University of Science and Technology, Tainan.

[3] Kuo, Y. C. (2015). "Hostels with stories \& the stories of hostels: Using renovated old houses as hostels [in Chinese]." (Master thesis), National Kaohsiung University of Applied Science, Kaohsiung.

[4] Lo, C. H. (2015). "An Action Analysis of Old House Reuse in Tainan City [in Chinese]." (Master thesis), National Sun Yat-sen University, Kaohsiung.

[5] Fang, S. W. (2015). "A Preliminary Study on the Emergence of Re-using Old House in Tainan Midtown Area, 19942013 [in Chinese]." (Master thesis), National Cheng Kung University, Tainan.

[6] Huang, S. L. (2014). "The End of a Living Era: A Case Study of the Pseudo - Living Experience Caused by Phenomenon of "Old House, New Life." South Taiwan Seminar on Social Development, 2014.

[7] Jan, J. L. (2014). "A study on the spatial atmosphere by revitalization of old houses in historical Tainan city [in Chinese]." (Master thesis), National Cheng Kung University, Tainan.

[8] Kao, C. C., and Lee, G. W. (2013). "Convenience Store Site Selection Analysis in Hsinchu City." Geographic Information System, vol. 10, no. 3, pp. 25-28.

[9] Cheng, H. H. (2013). "Mechanism of Regeneration in Old Urban Districts of Tainan from the Perspectives of District Configuration and Cultural Revitalization.” Journal of City and Planning, vol. 40, no. 3, pp. 267-286.

[10] Tsou, K. W., Cheng, H. T., Kuo, H. F., and Yang, T. M. (2013). "Applying Spatial Hedonic Price Model to Explore the Effects of Taiwan High Speed Railway on Land Price." Journal of City and Planning, vol. 14, no. 1, pp. 47-66.

[11] Wang, W. L. (2013). "The phenomenal development of revitalization of private houses as art and culture spaces using West Central District, Tainan City as example. [in Chinese]." (Master thesis), Yuan Ze University, Taoyuan.

[12] Wang, C. C. (2013). “Applying Fuzzy Delphi Method on Factors of Sports Bar Site Selection.” Journal of Sports Knowledge, vol. 7, no. 10, pp. 15-32.

[13] Lin, Y. J. (2012). "The strategy of spatial transformation and the meaning of social phenomenon of reuse for old house: in the case of "Old House, New Life" movement in Tainan [in Chinese]." (Master thesis), National Cheng Kung University, Tainan.

[14] Tsai, Y. C. (2012). "Research of Old House Operation of Historic Area in Tainan City [in Chinese]." (Master thesis), National Cheng Kung University, Tainan.

[15] Tseng, C. S. (2012). "The relationships between the store images and customer value of small individual coffee shopsOld-style cafe in Tainan as main objects [in Chinese].” (Master thesis), National Kaohsiung University of Hospitality and Tourism, Kaohsiung.

[16] Huang, P. D. (2011). "A Research of Operation model of Store location Selection- A Case Study of chain Breakfast Store [in Chinese]." (Master thesis), National Taipei University, Taipei.

[17] Yang, C. C., Chu, K. C., and Lin, W. C. (2010). "Location Selection Optimization Model for the Competitive Chain of Retail Stores." Journal of Ching-Yun University, vol. 30, no. 3, vol. 93-112.

[18] Lin, J. J., and Chang, Y. C. (2006). "The Shop Rents Analysis of Underground Arcades in Taipei Metro System: Application of Hedonic Price Approach." Journal of Architecture and Planning, vol. 7, no. 1, pp. 47-69.

[19] Timothy J. Fik, David C. Ling and Gordon F. Mulligan. (2003), "Modeling Spatial Variation in Housing Prices: A Variable Interaction Approach" REAL ESTATE ECONOMICS, vol. 31, no. 4, pp. 623-646.

[20] "The analysis of the historical building reusing in Kaohsiung", Kaohsiung Architects Association, 1994.

[21] Kelvin J. Lancaster. (1996), “A New Approach to Consumer Theory”, Journal of Political Economy, vol. 74, no. 2, pp. 132-157.

[22] Wilkes, Joseph A.(ed.)(1988). Encyclopedia of Architecture, Design Engineering \& Construction. New York, John Wiley \& Sons. 
[23] B. Curtis Eaton and Richard G. Lipsey (1975), "The Principle of Minimum Differentiation Reconsidered: Some New Developments in the Theory of Spatial Competition", OXFORD JOURNALS, vol. 42, no. 1, pp. 27-49.

[24] Sherwin Rosen. (1974), "Hedonic Prices and Implicit Markets: Product Differentiation in Pure Competition", Journal of Political Economy, vol. 82, no. 1, pp. 34-55 